Gut, 1987, 28, 1460-1466

\title{
Absence of complement fixing antibodies against lipopolysaccharides from Escherichia coli in a subgroup of patients with Crohn's disease
}

\author{
M ZEITZ, U HOPF, B WUST, C GALANOS, B MÖLLER, T J LAWLEY, \\ AND E O RIECKEN \\ From the Departments of Medicine, Klinikum Steglitz and Klinikum Charlottenburg, Free University Berlin; \\ Institute for Immunobiology, Freiburg, FRG; Dermatology Branch, National Cancer Institute, \\ National Institutes of Health, Bethesda, MD, USA
}

SUMmary Complement fixing antibodies against different Escherichia coli lipopolysaccharides were determined in patients with Crohn's disease and in healthy individuals and compared with antitetanus toxoid antibodies. All healthy individuals had antilipopolysaccharide antibodies, 10 of 27 patients with Crohn's disease had no antibodies and six had rapidly changing antibody titres. These abnormalities were found in patients with disease in the colon, with arthropathy and fistula. Antilipid A was found at lower titres in Crohn's disease. Neither antitetanus toxoid antibodies, nor immunoglobulin concentrations were different in patients with or without antilipopolysaccharide antibodies. There was no evidence for circulating immune complexes in patients lacking antilipopolysaccharide antibodies. Certain subgroups of patients with Crohn's disease have altered antibody levels to typical enteral antigens which most likely can be explained by local antibody binding to lipopolysaccharides at inflammatory sites, or by changes in immunoregulation in this disease.

Although the aetiology of Crohn's disease (CD) is unknown, there is evidence that alterations in immunoregulation and immune effector mechanisms may be involved in disease pathogenesis. ${ }^{1-4}$ Studies of $T$ and $B$ cell function in $C D$ have not resulted in the description of a well characterised abnormality. Circulating $\mathrm{B}$ cells from $\mathrm{CD}$ patients have been shown to spontaneously secrete more immunoglobulins compared with controls. "Circulating and gut derived lymphocyte populations have an increased proliferation when exposed to B cell mitogens, such as lipopolysaccharides (LPS).' These results correlate with the finding of raised antibody titres that react with various dietary and faecal microbial antigens in patients with inflammatory bowel disease. ${ }^{-11}$ Several studies suggest, however, that at least in a subgroup of $C D$ patients humoral

Address for correspondence: Dr Martin Zeitz. Medizinische Klinik. Klinikum Steglitz der FU Berlin. Hindendurgdamm 30. I(k)0 Berlin 45. West Germany. Received for publication 23 April. 1987. immune responses can also be decreased. ${ }^{12-1+}$ The data on humoral immune responses to various stimuli in patients with $\mathrm{CD}$ are therefore conflicting.

In the present study we took advantage of the fact that healthy individuals usually have high titres of circulating, complement fixing antibodies against purified LPS preparations from various Escherichia coli serotypes. ${ }^{15}$ To see if $\mathrm{CD}$ patients have an altered response to these enteral bacterial antigens, we determined complement fixing circulating anti-LPS antibodies and antilipid $\mathrm{A}$ antibodies in a follow up period during and after flareup of the disease and compared anti-LPS antibody titres with the presence of IgG antitetanus toxoid antibodies. Three different serotypes of $E$ coli were investigated because of their significance in human disease: serotype $\mathrm{O} 14$ possesses the so-called enterobacterial common antigen of Kunin which has crossreactivity with human colonic epithelial cells, ${ }^{1617}$ serotypes O75 and O119 are common in the human faecal flora and frequently involved in urinary tract infections. 


\section{Methods}

\section{PATIENTS}

The study was carried out in 27 patients with Crohn's disease. The diagnosis was established by endoscopical, radiological and histological criteria. Eleven men and 16 women were investigated; age ranged between 15 and 56 years (median 32 years). The study included eight patients with colonic disease, six with small bowel disease and 13 with both colon and small bowel involvement. The disease activity was evaluated by the Crohn's disease activity index (CDAI). ${ }^{\text {Is }}$ Twelve patients were followed up over a period of six months during and after treatment for active disease. Patients $(\mathrm{CDAI}>200)$ were treated with 6-methyl-prednisolone at a decreasing dose starting with $48 \mathrm{mg}$ and sulphasalazine $3 \mathrm{~g} /$ day $(\mathrm{n}=8)$ or with continuous intraduodenal infusion of a peptide diet (Peptisorb, Pfrimmer, FRG) through a filiform tube with a peristaltic pump without any drug treatment $(n=4)$. The other 15 patients were on a maintenance dose of prednisolone (dose ranging between 10 and $20 \mathrm{mg}$ per day) $(n=8)$ and/or sulphasalazine ( 3 g per day) $(n=5)$, seven patients had no drug treatment at the time of the study and two patients received azathioprine $2 \mathrm{mg} / \mathrm{kg}$ bodyweight. Twenty age and sex matched normal subjects, including blood bank donors and laboratory personnel, were used as controls.

PREPARATION OF L.PS AND FREE LIPID A Smooth form LPS from $E$ coli O119, O75, and O14 and alkali treated lipid A from electrodialysed Salmonella minnesota R 959 LPS were isolated as previously described. "1"-21

HAEMOLYTIC ASSAY

Washed sheep red blood cells (SRBC) were sensitised by incubation with LPS or lipid A for 30 minutes at $37^{\circ} \mathrm{C}$. The sheep red blood cells were then washed in PBS and suspended in veronal buffer $(\mathrm{pH} \mathrm{7.2)}$, reaching a $0.5 \%$ suspension. All sera were preabsorbed with washed sheep red blood cells. The assay was done on microtitre plates with a $1: 1$ mixture of different dilutions of the serum samples and LPS- or lipid A-sensitised sheep red blood cells, finally, $25 \mu \mathrm{l}$ guinea pig serum (preabsorbed with sheep red blood cells) were added as a source of complement. The plates were incubated for one hour at $37^{\circ} \mathrm{C}$ and haemolysis was evaluated visually."

The specificity of the antibodies determined in the haemolytic assay was confirmed by absorption tests. Serum samples of $250 \mu \mathrm{l}$ were incubated for one hour at $37^{\circ} \mathrm{C}$ with $500 \mu \mathrm{l}$ packed sheep red blood cells coated with different LPS. The sera were retested in the haemolytic assay after centrifugation. After these absorption procedures, the haemolytic titres were abolished for the absorbing antigen but not for the other LPS antigens, confirming the specificity of the antibody for the absorbing antigen.

ELISA FOR ANTITETANUS TOXOID SPECIFIC IgG Ninety six well flat bottom plates (Immulon I, Dynatech Laboratories, Alexandria, VA, USA) were coated with 100 $\mu$ l tetanus toxoid (Wyeth Laboratories Inc, Marietta, PA. USA) at a concentration of 1 flocculation unit (If)/ml in $50 \mathrm{mmol} / \mathrm{l}$

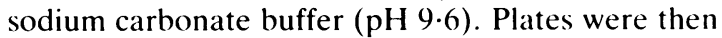
washed with PBS containing (0.05\% Tween 20 after each of the following steps. Non-specific binding was blocked with $10 \%$ bovine serum albumin. Serum samples from each subject were incubated in four dilutions, each dilution in duplicate, for two hours at $37^{\circ} \mathrm{C}$. A 1:1000 dilution of heavy chain specific goat antihuman IgG conjugated to alkaline phosphatase (Tago Inc, Burlingame, CA, USA) was added to each well and the plates were incubated for two hours. As the final step, $100 \mu \mathrm{l}$ of a $1 \mathrm{mg} / \mathrm{ml}$ solution of p-nitrophenyl phosphate (Sigma Chemical Comp. St Louis, MO, USA) in $10 \%$ diethanolamine buffer (pH 9.8) was added. Colour development was quantified at a wavelength of $405 \mathrm{~nm}$ by using a spectrophotometer (ImmunoReader NJ- 200, InterLab, Thousand Oaks, CA, USA). Optical density values were converted into immunoglobulin concentrations by comparison with a standard serum with a known amount of TT-specific IgG. The reference serum to calculate the TT-specific IgG concentration in the standard serum was kindly provided by Dr L G Lum, Fred Hutchinson Cancer Research Center, University of Washington, School of Medicine, Seattle, Washington, USA." Calculations were done using regression analysis after log transformation of the concentration values.

QUANTIFICATION OF IMMUNOGI.OBULIN CONCENTRATIONS

$\operatorname{IgG}, \operatorname{IgM}$ and $\operatorname{IgA}$ were estimated as described by Mancini et al $^{2+}$ with commercial Partigen plates (Behringwerke, Marburg, FRG).

DETERMINATION OF CIRCUIATING IMMUNE

COMPLEXES

Circulating immune complexes in sera of CD patients were determined by the $\mathrm{Clq}$ binding assay as described previously. ${ }^{\circ}$

STATISTICAL ANALYSIS

Results were expressed as median, minimum, and maximum and the Krukal-Wallis non-parametric analysis of variance was done to compare more than two different groups for significant differences. 
Table 1 Prevalence and titres of complement fixing antibodies against lipid $A$ and purified lipopolysaccharide (LPS) preparations from three different E coli strains $(O 119$, $O 75$ and O14) as determined in the haemolytic assay in healthy individuals and in patients with Crohn's disease

\begin{tabular}{|c|c|c|c|c|}
\hline & \multicolumn{2}{|c|}{ Controls $(n=20)$} & \multicolumn{2}{|c|}{ Crohn's disease $(n=27)$} \\
\hline & $\operatorname{Pos}(n)$ & Titres & $\operatorname{Pos}(n)$ & Titres \\
\hline Lipid A & $4 / 20 *$ & $\begin{array}{c}1: 16 \dagger \\
(1: 8-1: 32) \ddagger\end{array}$ & $3 / 27$ & $\begin{array}{c}1: 3 \\
(1: 2-1: 4)\end{array}$ \\
\hline LPS-E coli O119 & $20 / 20$ & $\begin{array}{c}1: 128 \\
(1: 8-1: 4098)\end{array}$ & $11 / 27$ & $\begin{array}{c}1: 128 \\
(1: 32-1024)\end{array}$ \\
\hline LPS-E coli O75 & $20 / 20$ & $\begin{array}{c}1: 128 \\
(1: 16-1: 2048)\end{array}$ & $11 / 27$ & $\begin{array}{l}1: 64 \\
\left(1: 16-1: 10^{6}\right)\end{array}$ \\
\hline LPS-E coli O14 & $20 / 20$ & $\begin{array}{c}1: 128 \\
(1: 64-1: 2048)\end{array}$ & $11 / 27$ & $\begin{array}{c}1: 128 \\
(1: 64-16384)\end{array}$ \\
\hline
\end{tabular}

${ }^{*}$ Number of healthy individuals or Crohn's discase patients with anti-LPS antibodies/total number investigated; †Median; $¥$ Range (minimum-maximum).

\section{Results}

ANTIBODIES AGAINST FREE LIPID A Complement fixing, haemolytic antibodies against free lipid A were detected in four of 20 healthy individuals and only in low titres (Table 1). Only three of 27 patients with CD had detectable amounts of antilipid $\mathrm{A}$; in these patients, antibody titres were below those of the control group (Table 1). Patients with antilipid $\mathrm{A}$ antibodies had active disease and the disease was located in the colon and small bowel. Two patients had perianal fistula.

ANTIBODIES AGAINST LIPOPOLYSACCHARIDES FROM E COLI O119, O75 AND O14

Complement fixing antibodies against highly purified LPS from three different $E$ coli strains as detected in a passive haemolytic assay could be shown in the sera from all healthy individuals (Table 1). The frequency and distribution of the serum titres in the control group was comparable for the different $E$ coli serotypes (one representative example is shown in Figure 1). In contrast, only 11 of 27 patients with CD had haemolytic antibodies against LPS from $E$ coli O119, O75, and O14 (Table 1). Ten patients had no detectable antibodies in the haemolytic assay against the different LPS preparations at any time point during their follow up. In comparing the distribution of antibody titres in CD patients and controls, it was apparent that the patients fell into one of two groups: one without antibodies (10 of 27 patients) and one with a similar distribution of antibody titres as the controls (17 of 27 patients) (Fig. 1). Patients with active and inactive disease were distributed randomly between the antibody positive and antibody negative group suggesting that disease activity does not influence the presence of anti-LPS antibodies. In most

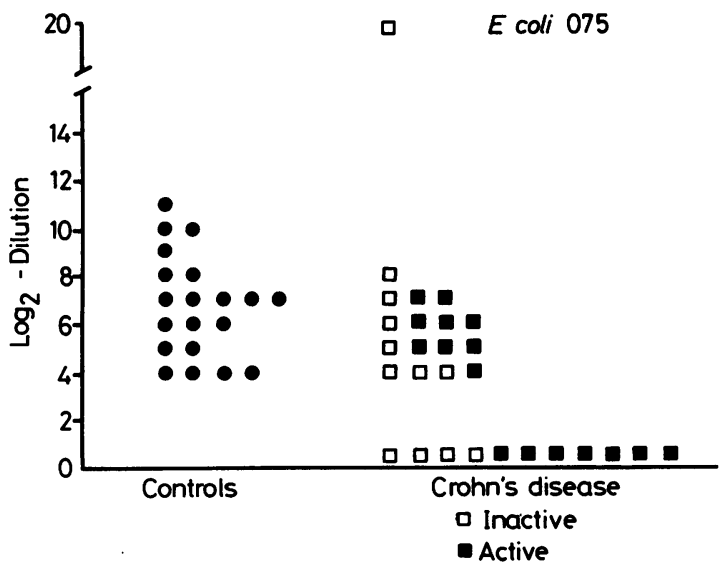

Fig. 1 Distribution frequency of titres of complement fixing antibodies against lipopolysaccharides from $E$ coli $O 75$ in patients with Crohn's disease $(n=27)$ and in healthy individuals $(n=20)$. Titres are expressed as $\log _{2}$-dilution and patients with active disease $(C D A I>200)$ are indicated. Antilipopolysaccharide antibodies against $E$ coli $O 75$ are shown as representative example, the distribution of antibody titres against lipopolysaccharides from E coli O14 and 0119 were comparable with this example.

cases patients in these two antibody groups remained in these groups upon repeat study. In six of $27 \mathrm{CD}$ patients studied, however, rapidly changing titres were noted as indicated in the representative patient antibody profile shown in Figure 2. The antibody titre changes in this patient subgroup could not be related to disease activity.

In the antibody positive group, three patients were treated with 6-methyl-prednisolone, three with 6-methyl-prednisolone and sulphasalazine, one patient received azathioprine in addition to prednisolone and sulphasalazine, and five were without treatment. In the antibody negative group, four patients were treated with 6-methyl-prednisolone, one with 6-methyl-prednisolone and sulphasalazine, one only with sulphasalazine, two patients were on a residue free oligopeptide diet alone and two had no treatment. Three of six patients with rapidly changing antibody titres were treated with 6-methylprednisolone and sulphasalazine, one on azathioprine alone, one treated with an elemental diet alone and one without treatment. Thus, the form of treatment had no influence on the anti-LPS antibody titres.

In Table 2, the influence of disease location within the bowel, the presence of extraintestinal manifestations and the presence of fistula on anti-LPS antibody titres is shown. Of the patients with colon involvement one had normal titres of anti-LPS antibodies, three had no detectable antibody titres and four had 

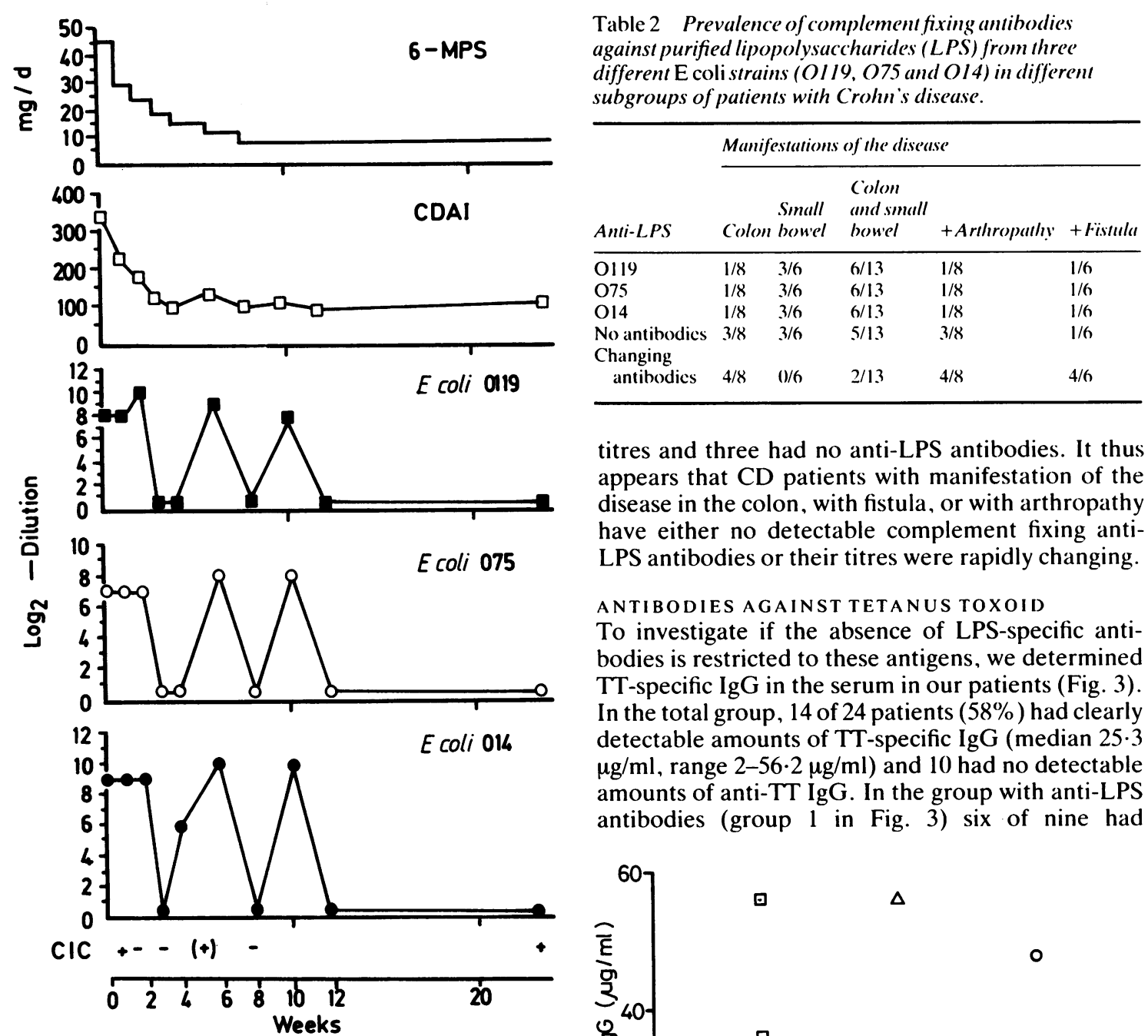

Fig. 2 Time course of the CDAI, of antibody titres against lipopolysaccharides from $\mathrm{E}$ coli $\mathrm{O} 14, \mathrm{O} 75$ and $O 119$, and of the presence of circulating immune complexes (CIC) in a patient with Crohn's disease of the colon. Therapy during flare up of the disease with 6-methyl-prednisolone (6-MPS) is indicated in the upper part of the figure.

rapidly changing antibody titres. A similar constellation was found for patients with arthropathy: one of eight patients had antibodies, three were antibody negative, and four were rapidly changing. In the group of patients with arthropathy, six had only colon involvement and two had colon and small bowel manifestations. Of the six patients with fistular disease, one had no detectable antibodies and four were rapidly changing. Of the six patients with small bowel manifestation only, three had normal anti-LPS
Table 2 Prevalence of complement fixing antibodies against purified lipopolysaccharides (LPS) from three subgroups of patients with Crohn's disease.

titres and three had no anti-LPS antibodies. It thus appears that $\mathrm{CD}$ patients with manifestation of the disease in the colon, with fistula, or with arthropathy have either no detectable complement fixing antiLPS antibodies or their titres were rapidly changing.

\section{ANTIBODIES AGAINST TETANUS TOXOID}

To investigate if the absence of LPS-specific antibodies is restricted to these antigens, we determined TT-specific IgG in the serum in our patients (Fig. 3). In the total group, 14 of 24 patients $(58 \%)$ had clearly detectable amounts of TT-specific IgG (median 25.3 $\mu \mathrm{g} / \mathrm{ml}$, range $2-56 \cdot 2 \mu \mathrm{g} / \mathrm{ml}$ ) and 10 had no detectable amounts of anti-TT IgG. In the group with anti-LPS antibodies (group 1 in Fig. 3) six of nine had

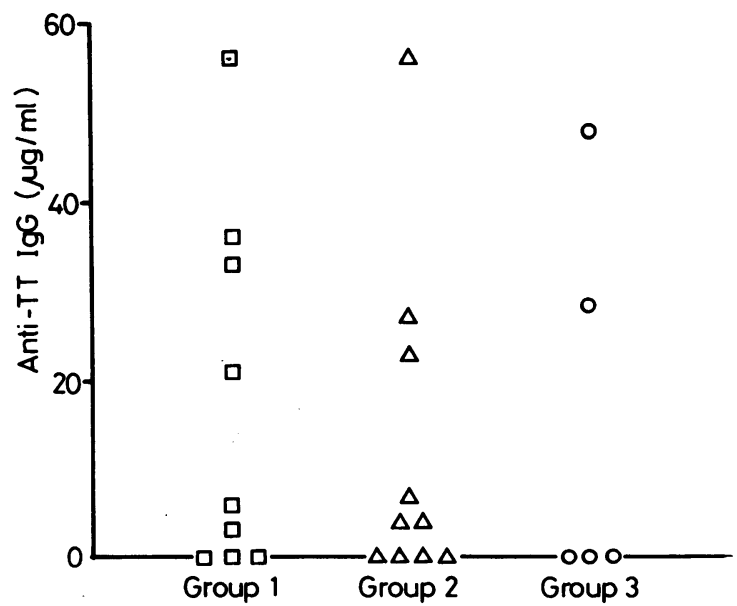

Fig. 3 IgG-antibodies against tetanus toxoid as measured by ELISA in the sera of patients with Crohn's disease. Group I refers to patients with haemolytic antibodies against lipopolysaccharides from E coli; group 2 to patients without antilipopolysaccharide antibodies; group 3 to patients with rapidly changing antilipopolysaccharide antibodies. No significant differences between the three groups were found with the Kruskal-Wallis test. 
Table 3 Serum immunoglobulin concentrations in three subgroups of patients with Crohn's disease. Comparing the Ig-concentrations for the particular isotypes between the three subgroups by the Kruskal-Wallis non-parametric analysis of variance, no significant differences were obtained.

\begin{tabular}{|c|c|c|c|c|c|c|c|c|c|}
\hline & \multicolumn{3}{|l|}{ Group $1^{*}$} & \multicolumn{3}{|l|}{ Group $2+$} & \multicolumn{3}{|l|}{ Group $3 \ddagger$} \\
\hline & $\lg G$ & $\lg M$ & $\operatorname{Ig} A$ & $\lg G$ & $\lg M$ & $\lg A$ & $\lg G$ & $\lg M$ & $\lg A$ \\
\hline Median & $13.1 \$$ & 1.7 & 2.5 & $12 \cdot 5$ & $2 \cdot 2$ & 1.9 & $11 \cdot 6$ & $2 \cdot 4$ & $2 \cdot 1$ \\
\hline Range & $7 \cdot 5-23 \cdot 7$ & $1 \cdot()-2 \cdot 3$ & $1 \cdot 5-7.9$ & $8 \cdot(1-16 \cdot 9$ & $1 \cdot 1-3 \cdot 2$ & $1 \cdot 3-3 \cdot 8$ & $10 \cdot 2-12 \cdot 8$ & $1 \cdot 8-4 \cdot 1$ & $1 \cdot 7-3 \cdot 4$ \\
\hline
\end{tabular}

*Paticnts with hacmolytic antibodics against lipopolysaccharides from $E$ coli; $†$ Paticnts without antilipopolysaccharide antibodics: $\ddagger$ Patients with rapidly changing antilipopolysaccharide antibodies; $\$$ Values are given as $\mathrm{g} / \mathrm{l}$.

detectable anti-TT IgG (median $27 \cdot 3 \mu \mathrm{g} / \mathrm{ml}$, range 2 $55 \cdot 6 \mu \mathrm{g} / \mathrm{ml})$, in the group without anti-LPS antibodies (group 2 in Fig. 3) six of 10 individuals had anti-TT IgG in the serum (median $14 \cdot 1 \mu \mathrm{g} / \mathrm{ml}$, range $3 \cdot 6-56 \cdot 2 \mu \mathrm{g} / \mathrm{ml})$ and in six patients with rapidly changing antibody titres against LPS from $E$ coli (group 3 in Fig. 3) two were found to have anti-TT IgG $(28.5 \mu \mathrm{g} / \mathrm{ml}$ and $48 \mu \mathrm{g} / \mathrm{ml})$. Comparing the three groups, no significant differences were found. The failure to detect complement fixing anti-LPS antibodies in patients with CD was not paralleled by an absence of TT-specific IgG-antibodies.

SERUM IMMUNOGLOBULIN CONCENTRATIONS IN PATIENTS WITH CROHN'S DISEASE

Serum concentrations of $\operatorname{IgG}, \operatorname{IgM}$ and $\operatorname{IgA}$ in the patients with $\mathrm{CD}$ fell within the reference values except for three patients with slightly raised IgM concentrations $(3 \cdot 19,4 \cdot 12$ and $3 \cdot 4 \mathrm{~g} / \mathrm{l}$, reference range: $0 \cdot 6-2 \cdot 8 \mathrm{~g} / \mathrm{l})$, one patient with raised $\mathrm{IgG}$ concentration $(23.7 \mathrm{~g} / \mathrm{l})$, and one patient with a slightly decreased $\mathrm{IgG}$ concentration $(7.5 \mathrm{~g} / \mathrm{l}$, reference range for IgG: $8 \cdot(0-18 \mathrm{~g} / \mathrm{l})$. Comparing total $\mathrm{IgG}$, $\operatorname{IgM}$ and $\operatorname{IgA}$ concentrations in the three subgroups of CD patients defined by the presence of anti-LPS antibodies, no significant differences were found (Table 3). In those patients whose antibody titres against LPS were rapidly changing, total immunoglobulin concentrations remained constant during the observation period (data not shown). The absence of antibodies against LPS was, therefore, not paralleled by changes in total immunoglobulin concentration.

CIRCULATING IMMUNE COMPLEXES IN PATIENTS WITH CROHN'S DISEASE

In nine patients with $C D$, circulating immune complexes were determined by the $\mathrm{Clq}$ binding assay: in one of three patients with high titres of complement fixing antibodies to LPS from $E$ coli there was evidence for circulating immune complexes. None of three patients without detectable anti-LPS antibodies had evidence of circulating immune complexes. In three patients with rapidly changing
anti-LPS antibody titres, circulating immune complexes were measured in parallel and there was no correlation between low or undetectable anti-LPS antibodies and the presence of circulating immune complexes (example shown in Fig. 2).

\section{Discussion}

In the present study we have investigated the presence of complement fixing antibodies against purified LPS preparations from three different $E$ coli strains and against free lipid $\mathrm{A}$, the strain non-specific component of bacterial lipopolysaccharides, in patients with $C D$ and in healthy individuals. The major findings of this study are that (a) certain subgroups of CD patients have an altered response pattern of antiLPS antibodies in comparison with healthy individuals and (b) that these alterations are not paralleled by changes in specific antibodies to another common antigen (TT), in total immunoglobulin concentrations or by the presence of circulating immune complexes. There is general agreement in most previous studies that patients with inflammatory bowel disease have an increased prevalence and increased titres against faecal microbial antigens. ${ }^{x-11}$ This finding is attributed to an increased absorption of bacterial antigens through the intestinal epithelium damaged by the chronic inflammation. Our own finding of decreased or absent complement fixing anti-LPS antibodies in patients with CD therefore seems to be at variance with these previous studies. One possible explanation is that different antibody assays were used. In most previous studies either agglutinating serum antibodies using bacterial suspensions or haemagglutinating antibodies were determined, whereas in our study complement fixing haemolytic antibodies were measured. Another possible explanation is that different antigenic preparations were used. In our study we used purified LPS preparations from three different $E$ coli strains. Complement fixing antibodies against these LPS preparations were present in all healthy individuals investigated, a finding which confirms earlier observations. ${ }^{15}$ 
Antibodies against lipid $\mathrm{A}$, the common antigenic component of LPS-molecules from most gram negative bacteria, were rarely observed in either the control group or in patients with CD. Without exception, however, patıents with $C D$ had lower antilipid A titres as compared with healthy individuals. This finding is in agreement with a recent study showing decreased concentrations of antilipid A IgG in patients with inflammatory bowel disease, especially in patients with extensive colon involvement." Conflicting data were obtained in other studies in which increased antilipid $\mathrm{A}$ antibody titres in patients with CD were found. ${ }^{72}$ Because our study has clearly shown that $C D$ patients are heterogeneous in their anti-LPS response, the difference may lie in the fact that different patient populations were studied.

The absence of anti-LPS antibodies or the presence of rapidly changing antibody titres in subgroups of $C D$ patients can be explained in several ways. First, patients with low antibody titres could have had circulating LPS which bound the anti-LPS antibodies and interfered with our test system. In this case, one would have expected the occurrence of circulating immune complexes especially in the patients with fluctuating antibody titres. In agreement with previous reports, however, ${ }^{\text {"M: : }}$ we found infrequently evidence for circulating immune complexes in $C D$ patients, and the presence of these immune complexes did not correlate with the failure to measure anti-LPS antibodies. In addition, using dot blot analysis to detect the antigenic determinants in immune complexes, there was no evidence for LPScontaining antigen antibody complexes in CD sera (unpublished observations). These findings make it unlikely that circulating LPS and immune complex formation account for our inability to measure antiLPS antibodies. Another possibility is that in patients with low or absent LPS antibody titres the antibodies are bound in various tissue sites, especially those located in the intestinal mucosa. In this view, patients with certain types of discase or levels of disease activity allow entry of LPS antigens into the mucosa and this leads to depletion of circulating anti-LPS antibodies as the serum passes the mucosa.

Another possibility is that the changes in anti-LPS antibody titres are caused by changes in antibody synthesis and secretion in certain patient subsets. Thus, in a recent study it has been shown that patients with CD or ulcerative colitis have a defective generation of tetanus toxoid specific antibody producing $B$ cells after in vivo immunisation. " In addition, while normal levels of Ig-synthesis in in ritro pokeweed mitogen driven systems of unseparated peripheral blood lymphocytes in CD was found, after lymphocyte separation procedures circulating $T$ cells that could profoundly suppress Ig-synthesis were detected in many patients. ${ }^{1: 14}$ It is therefore possible that our failure to measure antibodies against LPS in some patients with $C D$ is because of the occurrence of suppressor cells which suppress synthesis and/or secretion of LPS-specific antibodies. A further point is that a potential immunoregulatory defect in inflammatory bowel disease is most likely to be located in the mucosal lymphoid system. This could explain the differences in the antibody response to TT and LPS of CD patients shown here as LPS from $E$ coli are typical enteral antigens whereas TT is a systemic antigen.

In conclusion, our study on complement fixing serum antibodies in patients with $C D$ has provided evidence that certain subgroups of CD patients (patients with colon involvement only, patients with fistula, or patients with arthropathy) have altered antibody levels to LPS obtained from different $E$ coli strains, whereas no such alteration could be shown for another, non-enteral antigen (TT). The fact that we found no evidence for circulating immune complexes which could explain our failure to measure anti-LPS antibodies point to the possibility that either local antibody binding to LPS at inflammatory sites occurs or a more fundamental immunoregulatory defect exists.

The authors thank Drs Warren Strober and Stephen P James, Mucosal Immunity Section, NIAID. National Institutes of Health. Bethesda, USA, for critical review of the manuscript. This work was supported by the Deutsche Forschungsgemeinschaft. Ho 752/4-4. Parts of this study were performed during a fellowship of $\mathrm{M}$ Zeitz at the Mucosal Immunity Section. NIAID, National Institutes of Health. Bethesda, Maryland, USA. This fellowship was supported by the Deutsche Forschungsgemeinschaft, Ze 188/3-1. Part of this work has been published as preliminary report in abstract form (Gastrocenterology 1985: 88: 1642).

\section{References}

1 Kralt SC. Kirsner JB. The immunology of ulcerative colitis and Crohn's discasc: clinical and humoral aspects. In: Kirsner JB. Shorter R( , eds. Inflammatory bowel disease. Philadelphia: Lea \& Febiger, 1975: $6(1)-8()$.

2 Watson DW. Shorter R(i. The immunology of ulcerative colitis and Crohn's discase: (ell-mediated immunc responses. In: Kirsner JB. Shorter R(i. eds. Inflammatory bowel disease. Philadelphia: Lea \& Febiger, 1975: $81-98$.

3 Strober $W$. The regulation of the mucosal immune system. J Allergy (lin lmmunol 1982: 70): 22.5-30).

4 Jewell DP. Patci ( Immunology of inflammatory bowel discase. Scand I (iastrochterol 1985: (suppl) 114: 119-26. 
5 MacDermott RP. Nash (iS. Bertovich NJ. Sciden MV. Bragdon MJ. Bcale MCi. Alterations of IgM. IgCi and IgA synthesis and secretion by peripheral blood and intestinal mononuclear cells from patients with ulcerative colitis and Crohn is discase. (iastrocmerology 1981: 81: $8+4-52$.

6 Sicher (;. Herrmann F, Zcitz M. Teichmann H. Rühl H. Abnormalitics of B-cell activation and immunoregulation in patients with Crohn's discasc. (itl 1984; 25: 125.5-61.

7 Fiocehi C. Battisto JR, Farmer RG. Studies on isolated gut mucosal lymphocytes in inflammatory bowel discase. Detection of activated T cells and enhanced proliferation to $S$. aureus and lipopolysaccharides. Dig Dis Sci 1981: 26: $728-36$.

8 Thayer WR, Brown M. Sangree H, Katz J. Hersh T. Escherichia coli $O: 14$ and colon hemagglutinating antibodies in inflammatory bowel discase. (iastroenterology 1969: 57: 311-s.

9 Tabaychali S. OPonoghue DP. Bettelheim KA. Escherichia coli antibodies in patients with inflammatory bowel disease. (jut 1978: 19: 108-13.

10 Auer IO. Röder A, Wensinck F, van de Merwe JP. Schmidt H. Selected bacterial antibodies in Crohn's disease and ulcerative colitis. Scand $J$ Gastronterol 1983; 18: 217-23.

11 Blaser MJ, Miller RA, Lacher J, Singleton JW. Patients with active Crohn's disease have elevated serum antibodies of seven enteric bacterial pathogens. (jastroenterology 1984; 87: 888-94.

12 Stevens R, Oliver M. Brogan M. Heiserodt J, Targan S. Defective generation of tetanus-specific antibody-producing $B$ cells after in vivo immunization of Crohns discase and ulcerative colitis patients. (iastroemerology 1985; 88: 186060 .

13 Elson CO. Gracfi AS. James SP. Strober W. Covert suppressor T' cells in Crohn's discase. (iastroenterology 1981: 80: 1.51.3-21.

14 James SP, Neckers LM, Graeff AS, Cossman J, Balch CM, Strober W. Suppression of immunoglobulin synthesis by lymphocyte subpopulations in patients with Crohn's disease. Gastroenterology 1984; 86: 1510-8.

15 Möller B. Hopf U. Martin P. (jalanos ('. Detection and characterization of antibodies against lipopolysaccharides (LPS) from E. coli and free lipid $\Lambda$ in healthy subjects and patients with chronic liver discase [Abstract]. Immunobiology 1983; 165: 321.

16 Kunin CM. Separation, characterization, and biological significance of a common antigen in enterobacteriaceace. $J$ Exp Med 1963; $118: 56.5-80$.

17 Perlmann P. Hammerström S, Lagererantz R. Campbell D. Autoantibodies to colon in rats and human ulcerative colitis: cross reactivity with Escherichia coli O:14 antigen. Proc Soc Exp Biol Med 1967: 125: 97.5-80).

18 Best WR. Becktel JM. Singleton JW. Kern F. Development of a Crohn's discasc activity index. National cooperative Crohn's discase study. (iastroenterology 1976; 70: 439-44.

19 Westphal O. Lüderitz O. Bister F. Über die Extraktion von Bakterien mit Phenol/Wasser. Z Naturforsc/h 1953; 76: $148-55$.

20) (Balanos C. Lüderitz O. Electrodialysis of lipopolysaccharides and their conversion to uniform salt forms. Eur J Bioche'm 1975: 54: 60)3-10.

21 (Balanos (. Lüderitz O, Rietschel ET, Westphal O. Newer aspects of the biochemistry and biology of bacterial lipopolysaccharides with special reference to their lipid A component. In: Goodwin TW, ed. International review of biochemistry. Biochemistry of lipids II. Vol 14. Baltimore: University Park Press, 1977: $239-334$.

22 Galanos (. Lüderitz O. Westphal (). Preparation and properties of antisera against the lipid A component of bacterial lipopolysaccharides. Eur J Biochem 1971: 24: $116-22$.

23 Lum LG. Culbertson NJ. The induction of suppression of in vitro IgG anti-tetanus toxoid antibody synthesis by human lymphocytes stimulated with tetanus toxoid in the absence of in vivo booster immunization. J Immmunol 198.5: 135: 18.5-91.

24 Mancini G. Carbonara AO. Heremans IF. Immunochemical quantification of antigens by single radial immunodiffusion. Immunochemistry 196.5: 2: 23.5-54.

25 Lawley TJ, Moutsopoulos HM. Katz SI. Theofilopoulos AN. Chused TM. Frank MM. Circulating immunc complexes on Sjögren's syndrome. J Immunol 1979): 123: $1382-7$.

26 Mattsby-Baltzer I. Fasth A. Jaup B. Kaijser B. Nilson LA. Studies of antibodies to lipid $A$ and Tamm-Horsfall in patients with inflammatory bowel discasc. Scand $J$ Gastroenterol 1943: 18: 305-11.

27 Schüssler P. Kruis W. Marget W. Lipoid-A-Antikörpertiter bei Morbus Crohn. Klin Wochensche 1976; 54: $105.5-6$.

28 Kruis W. Schüssler P. Weinzierl M. (jalanos ('. Eisenburg J. Circulating lipid $\mathrm{A}$ antibodies despite absence of systemic endotoxemia in patients with Crohn's discasce. Dig I)is S(i 1984: 29: 502-7.

29 Hodgson HJ. Potter J. Jewell DP. Immune complexes in ulcerative colitis and Crohn 's discase. ( Cin Exp Immunol 1977: 29: 187-96.

30) Kemler B.J. Alpert E. Inflammatory bowel disease associated circulating immune complexes. (;ut 1980): 21 : $195-2() 1$.

31 Danis VA. Harries AD. Heatley RV. Antigen-antibody complexes in inflammatory bowel disease. Scand $J$ Gastronemerol 1984: 19: 60)3-6.

32 Hobbiss J. Cooper KM. Moore M. Gowland E, Schoficld PF. Limitations of immune complex measurements in colorectal discase. Br J Surg 1983; 70: 473-7.

33 Jewell DP. Macl ennan IC M. Circulating immune complexes in inflammatory bowel discase. (lin Exy /mmunol 1973: 14: 219-26. 